\title{
Cellular changes in boric acid-treated DU- 45 prostate cancer cells
}

\author{
WT Barranco' and CD Eckhert*, \\ 'Department of Environmental Health Sciences, University of California, Los Angeles, Box 95 I770, CA 90095-I772, USA
}

\begin{abstract}
Epidemiological, animal, and cell culture studies have identified boron as a chemopreventative agent in prostate cancer. The present objective was to identify boron-induced changes in the DU- I 45 human prostate cancer cell line. We show that prolonged exposure to pharmacologically-relevant levels of boric acid, the naturally occurring form of boron circulating in human plasma, induces the following morphological changes in cells: increases in granularity and intracellular vesicle content, enhanced cell spreading and decreased cell volume. Documented increases in $\beta$-galactosidase activity suggest that boric acid induces conversion to a senescentlike cellular phenotype. Boric acid also causes a dose-dependent reduction in cyclins A-E, as well as MAPK proteins, suggesting their contribution to proliferative inhibition. Furthermore, treated cells display reduced adhesion, migration and invasion potential, along with F-actin changes indicative of reduced metastatic potential. Finally, the observation of media acidosis in treated cells correlated with an accumulation of lysosome-associated membrane protein type 2 (LAMP-2)-negative acidic compartments. The challenge of future studies will be to identify the underlying mechanism responsible for the observed cellular responses to this natural blood constituent

British Journal of Cancer (2006) 94, 884-890. doi:I0.1038/sj.bjc.6603009 www.bjcancer.com

Published online 2I February 2006

(c) 2006 Cancer Research UK
\end{abstract}

Keywords: boric acid; prostate cancer; DU-|45; migration; senescence; acidosis

The element boron is nearly completely absorbed from drinking water and plant-derived foods in the gastrointestinal tract, and circulates in blood as boric acid (BA) (Price et al, 1997). Cells were once thought incapable of processing the element, yet this has since been disproved. Boron is utilised by bacteria in the structure of several antibiotics and autoinducer-2, a signalling molecule utilised during interspecies quorum sensing (Chen et al, 2002; Semmelhack et al, 2004). Plants require the element for growth, flowering and seed formation, and obtain boron from soil pore water using a borate transporter, BOR1, expressed in root pericycle cells (Takano et al, 2002). A human homologue, the electrogenic, voltage-regulated, $\mathrm{Na}^{+}$-coupled borate transporter $\mathrm{NaBCl}$, was recently identified in human kidney tubular cells and may function to maintain plasma BA levels (Park et al, 2004).

There are several reports supporting boron as a chemopreventative agent against prostate cancer. An epidemiological study using data from the NHANES III database reported that the risk of prostate cancer in US men is inversely proportional to dietary intake of boron (Cui et al, 2004). The biological plausibility of this observation has been supported by cell culture and animal studies. Treatment of nude mice, injected with androgen-sensitive LNCaP prostate cancer cells, with BA caused a reduction in tumour growth of $25-38 \%$, along with a reduction in plasma PSA levels of $88 \%$ (Gallardo-Williams et al, 2004). BA inhibits the activity of serine proteases, including prostate-specific antigen (PSA), presumably by binding to its active site (Bone et al, 1987; Gallardo-Williams

*Correspondence: Dr CD Eckhert; E-mail: ceckhert@ucla.edu Received 12 September 2005; revised 4 January 2006; accepted 17 January 2006; published online 2I February 2006 et al, 2003). In culture, BA has been shown to inhibit the proliferation of $\mathrm{LNCaP}$ and the androgen-independent prostate cancer cell lines DU-145 and PC-3, in a dose-dependent manner (Barranco and Eckhert, 2004). Since DU-145 cells do not synthesise PSA, BA's mode of inhibiting proliferation is likely not to occur by inhibiting the conversion of IGFBP-3 to IGF-1, as proposed in LNCaP tumours (Gallardo-Williams et al, 2004; Sobel and Sadar, 2005). The present investigation was initiated to define morphological and molecular responses of DU-145 prostate cancer cells to BA, which might lead to an explanation of its antiproliferative properties.

In the current report, we examined the effects of pharmacological concentrations of $\mathrm{BA}$ on cell morphology and molecular markers of proliferation, senescence, metastasis and motility. We show that prolonged exposure to BA causes DU-145 cells to develop a flattened, angular phenotype with numerous vesicles appearing in the cytoplasm. These changes occur coincident with a decrease in the expression of cyclin proteins, p21 and P-MEK1/2, as well as a reduction in cell motility and invasion capacity. Finally, increased $\beta$-galactosidase activity reflects a conversion of DU-145s to a senescence-like cell.

\section{MATERIALS AND METHODS}

\section{Experimental culture}

DU-145, LNCaP, and PC-3 PCa cells, donated by Dr Allan Pantuck, were cultured in RPMI 1640 media (Invitrogen, USA) supplemented with $10 \% \mathrm{FBS}$, penicillin/streptomysin $\left(100 \mathrm{U} \mathrm{ml}^{-1}\right.$; $100 \mu \mathrm{g} \mathrm{ml}^{-1}$ ), and L-glutamine (200 mM) (Gemini Bioproducts, 
USA). Experimental media was prepared as previously published in Barranco and Eckhert (2004). Cells were plated directly onto culture plates or glass coverslips and allowed to settle overnight in nontreated media. After $24 \mathrm{~h}$, media was aspirated and replaced daily, for 7-8 days, with BA-supplemented media $(0-1000 \mu \mathrm{M})$. Cell counts were performed using a hemacytometer and Trypan Blue (Invitrogen) for identifying nonviable cells.

\section{Flow cytometry}

Following 8 days in culture with BA $(0,250$, and $1000 \mu \mathrm{M})$, DU-145 cells were trypsinised, resuspended as $1 \mathrm{ml}$ aliquots $\left(10^{6}\right.$ cells ml $\left.{ }^{-1}\right)$ in loading buffer (RPMI 1640 w/o phenol red), and incubated in $12 \times 75 \mathrm{~mm}$ polystyrene test tubes for $30 \mathrm{~min}$, at $37^{\circ} \mathrm{C}, 5 \% \mathrm{CO}_{2}$. Following incubation, forward light scatter and side light scatter analysis (serving as measures of cell size and granularity, respectively) were determined using a Becton Dickinson BD-LSR analytic flow cytometer on samples of 10000 cells. Data analysis was performed with FLOWJO. Loading buffer was supplemented with Indo-1 AM $(1 \mu \mathrm{M})$ (Sigma, USA), a cell-permeable $\mathrm{Ca}^{2+}$ fluorescent probe, for concordant measurements of intracellular calcium.

\section{$\beta$-galactosidase assay}

Detection of $\beta$-galactosidase activity was determined using a previously published procedure (Dimri et al, 1995). DU-145 cells (8-day exposed), cultured on glass coverslips, were washed in PBS and fixed in $3 \%$ formaldehyde for $5 \mathrm{~min}$. Fixed cells were washed with $\mathrm{PBS}$ and incubated overnight at $37^{\circ} \mathrm{C}$ (low $\mathrm{CO}_{2}$ ) with fresh $\beta$-Gal stain solution $\left(1 \mathrm{mg} \mathrm{ml}^{-1} 5\right.$-bromo-4-chloro-3-indoyl $\beta$-Dgalactopyranoside (X-Gal), $40 \mathrm{~mm}$ citric acid/40 mM sodium phosphate $(\mathrm{pH} 4.0 \& 6.0), 5 \mathrm{~mm}$ potassium ferrocyanide, $5 \mathrm{~mm}$ potassium ferricyanide, $150 \mathrm{~mm} \mathrm{NaCl}, 2 \mathrm{~mm} \mathrm{MgCl}_{2}$ ). The percentage of cells testing positive for $\beta$-galactosidase activity (appearing blue) in four randomly selected optical fields were determined under light microscopy.

\section{Western blot}

DU-145 cells were cultured for 1,2 , and 7 days in the presence of BA $(0-1000 \mu \mathrm{M})$, on $100 \times 20 \mathrm{~mm}$ tissue culture plates, with daily media replacement. Following treatment, monolayers were washed with PBS, removed with a rubber policeman, and centrifuged at $1200 \mathrm{rpm}$ for $5 \mathrm{~min}$. For protein extraction, pellets were submerged in lysis buffer ( $250 \mathrm{~mm} \mathrm{NaCl}, 0.1 \%$ NP40, $50 \mathrm{~mm}$ HEPES (pH 7.0), $5 \mathrm{~mm}$ EDTA, $1 \mathrm{~mm}$ DTT, $10 \%$ protease inhibitor mixture (Sigma)), sonicated, and incubated for $40 \mathrm{~min}$ at $4{ }^{\circ} \mathrm{C}$. Wells of $10 \%$ stacking, $12 \%$ separating (SDS-PAGE) gels were loaded with $30 \mu \mathrm{g}$ of protein per sample and separated for $30 \mathrm{~min}$ at $100 \mathrm{~V}$, followed by $1 \mathrm{~h}$ at $200 \mathrm{~V}$. Separated proteins were transferred to nitrocellulose membranes for $4 \mathrm{~h}$ at $40 \mathrm{~V}, 4^{\circ} \mathrm{C}$. Membranes were blocked overnight (Nonfat dry milk $4 \mathrm{~g}, 38 \mathrm{~mm}$ Tris base, $125 \mathrm{~mm} \mathrm{NaCl}$ 2.5, $100 \mu \mathrm{l}$ Tween $20, \mathrm{ddH}_{2} \mathrm{O} 100 \mathrm{ml}$ ). The 2-h primary antibody exposure $(1 / 200-1 / 800$ dilution) was followed by a $10 \mathrm{~min}$ wash in PBS/Tween $20(0.1 \%)$ and 1-h secondary antibody exposure (1/ 1000 dilution) was followed by $3 \times 10 \mathrm{~min}$ washes in PBS/Tween 20 $(0.1 \%)$. Probed membranes were submerged in ECL detection reagent, (Amersham, USA), wrapped in cellophane, and exposed to $\mathrm{X}$-ray film (Fuji). All primary and secondary antibodies were purchased from Santa Cruz Biotechnology (Santa Cruz, CA, USA).

\section{Fluorescent probe detection of actin and acidic compartments}

For actin probing (F-actin, fluorescein phalloidin; G-actin, fluorescent deoxyribonuclease I conjugate) (Molecular Probes, USA), 8-day BA-treated DU-145 cells were washed $2 \times$ with PBS and fixed in PBS containing 3.7\% formaldehyde, for $10 \mathrm{~min}$ at room temperature. Fixed cells were washed $2 \times$ with PBS before being extracted with acetone $\left(-20^{\circ} \mathrm{C}\right)$ for $5 \mathrm{~min} .2 \times$ wash with PBS followed before cells were loaded with phalloidin $(0.16 \mu \mathrm{m}$ in $1 \% \mathrm{BSA} / \mathrm{PBS})$ or deoxyribonuclease I $(0.3 \mu \mathrm{M}$ in glycerol/PBS $)$ for $20 \mathrm{~min}$, at $37^{\circ} \mathrm{C}$. Loaded cells were washed $2 \times$ with PBS, mounted on slides, and viewed under confocal microscopy (Fluorescein: ex 496, em 516).

For intracellular acidic compartment labelling, 8-day BAexposed DU-145 cells were loaded with a nonspecific lysosome marker (LysoTracker Green) (Molecular Probes). Cells were submerged in prewarmed media containing LysoTracker $(1 \mu \mathrm{M})$ for $1 \mathrm{~h}$, at $37^{\circ} \mathrm{C}$. Following incubation, loading medium was aspirated, replaced with PBS, and cells were viewed under confocal microscopy (ex 504, em 511). All fluorescent images, along with light images, were recorded using an Axioskop 2 FS confocal microscope and brightened using Photoshop 6.0.

\section{Cell attachment, migration, and invasion assays}

For cell attachment efficiency calculations, DU-145 cells were cultured in the presence of BA $(0,250$, and $1000 \mu \mathrm{M})$ for 8 days on $100 \times 20 \mathrm{~mm}$ tissue culture plates, trypsinised and replated onto sixwell polystyrene culture plates (Fisher, USA) at $2.5 \times 10^{5}$ cells well $^{-1}$. Following a 24-h incubation, nonadherent cells and media were aspirated, while attached cells were trypsinised and counted.

The migration analysis protocol was identical to the attachment assay's, except that $2.5 \times 10^{5}$ cells were loaded in the upper migration chamber of a Corning transwell permeable support (24well transwell, $8-\mu \mathrm{M}$ polycarbonate membrane) in $0.1 \mathrm{ml}$ of serumfree RPMI-1640 media. RPMI-1640 $(0.6 \mathrm{ml})$ supplemented with $10 \%$ FBS, serving as a chemo-attractant, was deposited in the lower chamber. Plates were covered and incubated for $24 \mathrm{~h}$ at $37^{\circ} \mathrm{C}, 5 \%$ $\mathrm{CO}_{2}$. Following incubation, cells remaining on the upper filter were removed with a cotton swab, while the migrated population on the filter underside was washed with PBS, fixed in methanol, stained with Giemsa stain, rinsed with PBS, and deionised water, and allowed to air-dry. Cells in four random optical fields were counted to determine the number of migratory cells.

The invasion assay procedure was identical to that used in the migration analysis, except that each filter, prior to loading, was coated with $20 \mu \mathrm{g}$ of growth factor reduced-matrigel (BD biosciences) in $100 \mu \mathrm{l}$ of cold, serum-free RPMI-1640 media, and subsequently allowed to air-dry overnight in a sterile culture hood.

Since plating efficiency varied among BA-treated cells on matrigel-treated and untreated polycarbonate membranes, test cells were cultured alongside experimental cells and after incubation were trypsinised from filters, counted on a haemacytometer and used to determine the motility fraction.

\section{Media $\mathrm{pH}$ measurements}

Following 8-day BA (250 and $1000 \mu \mathrm{M}$ ) exposures to DU-145 cells, with daily media refreshment, media used for the $24 \mathrm{~h}$ period between day 7 and 8 was removed and the $\mathrm{pH}$ was measured using a Pinnacle $530 \mathrm{pH}$ meter (Corning). Cell counts were performed on the adherent cells from corresponding plates and utilised for calculating the $\mathrm{pH}$ shift per cell:

$$
\text { Acidic } \mathrm{pH} \text { shift per cell }=\frac{7.4-\text { observed } \mathrm{pH}}{\text { Cells per plate }\left(\times 10^{6}\right)} .
$$

\section{Statistics}

SigmaStat 3.1 statistical software (Systat Software, Point Richmond, CA, USA) was utilised for paired $t$-test. All experiments were performed in triplicate. 


\section{RESULTS}

\section{BA alters cell morphology, while inducing cellular senescence}

Flow cytometry and light microscopy were used to assess morphological alterations resulting from BA exposure. Following an 8-day exposure to BA $(0,250$, and $1000 \mu \mathrm{M})$, flow cytometry analysis showed a dose-dependent increase in cellular granularity (side light scatter) and a decrease in cell size (forward light scatter) (Figure 1A). No differences in cell morphology were apparent between confocal images of treated and untreated cells during the first 2 days. By day 8, treated DU-145 cells became flattened and contained numerous vesicles (Figure 1B).

BA's ability to inhibit cell proliferation without cell-death inspired our investigation to determine its effects on markers of senescence. The activity of $\beta$-galactosidase at $\mathrm{pH} 4.0$, a marker of senescence, increased with BA exposure in a dose-dependent manner (Figure 1C). Enzyme activity was not detected at $\mathrm{pH} 6.0$ (data not shown).

\section{BA alters proliferation-relevant protein expression}

DU-145 cells were exposed to BA $(0-1000 \mu \mathrm{M})$ for 1,2 , or 7 days. No changes were apparent at 1 or 2 days, but at 7 days, the protein expression of cyclins A, B1, C, D1, E, and the phosphorylated form of MAPK signaler MEK (P-MEK1/2) decreased at 500 and $1000 \mu \mathrm{M}$ concentrations (Figure 2A-F). Phosphorylated ERK
(P-ERK1/2) increased at intermediate exposures (100 and $250 \mu \mathrm{M})$, relative to control, but was reduced by higher concentrations of BA (Figure 2B). The tumour suppressor gene p53 expression remained stable, but p21 decreased following 7-day exposures (Figure 2H).

\section{BA induces cytoskeletal alterations, while inhibiting cell attachment, migration, and invasion}

Measurements were taken to assess cell attachment, migration, invasion, and intracellular cytoskeletal actin distribution to determine if BA (250 and $1000 \mu \mathrm{M})$ exposure for 8 days had an effect on metastasis-related aspects of cancer cells. Staining for filamentous (F)-actin, a marker for intercellular connections and extensions such as filopodia, was decreased in cells exposed to high levels of BA. A total of $1000 \mu \mathrm{M}$-treated cells had smoothedges and were angular in appearance (Figure 3A). Intracellular globular (G)-actin expression was unaltered by BA exposure.

BA-treated cells show a reduction in attachment efficiency to polystyrene culture dishes, with a drop in plating efficiency of $34 \%$ at $1000 \mu \mathrm{M}$ (Figure 3B). With $10 \%$ FBS serving as a chemoattractant, the capacity of DU-145 cells to migrate across an $8 \mu \mathrm{m}$ polycarbonate permeable membrane was reduced by 28 and $89 \%$, by 250 and $1000 \mu \mathrm{M} \mathrm{BA}$, respectively (Figure 3C). The same trend was observed with invasion potential, where 250 and $1000 \mu \mathrm{M}$ BA pretreatments reduced matrigel invasion by 82 and $97 \%$ (Figure 3C).
A

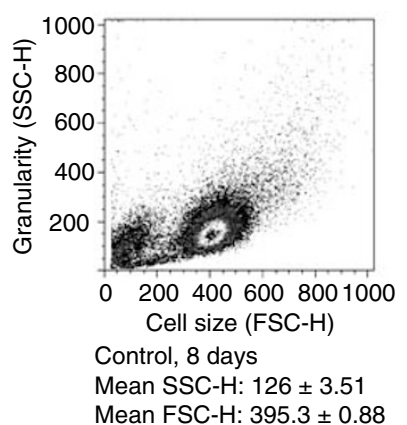

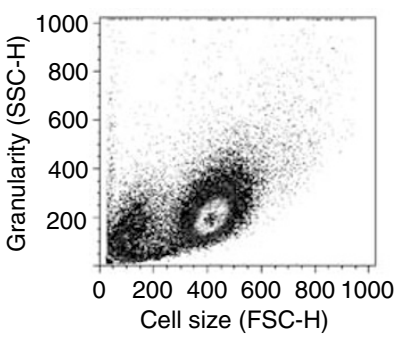

$250 \mu \mathrm{M}$ BA, 8 days Mean SSC-H: $139.7 \pm 1.76$

Mean FSC-H: $379.3 \pm 0.88$

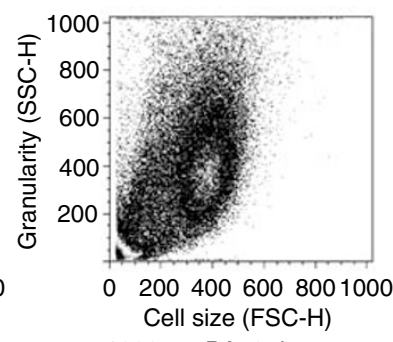

$1000 \mu \mathrm{M}$ BA, 8 days

Mean SSC-H: $415.3 \pm 4.48$

Mean FSC-H: $332.7 \pm 2.19$

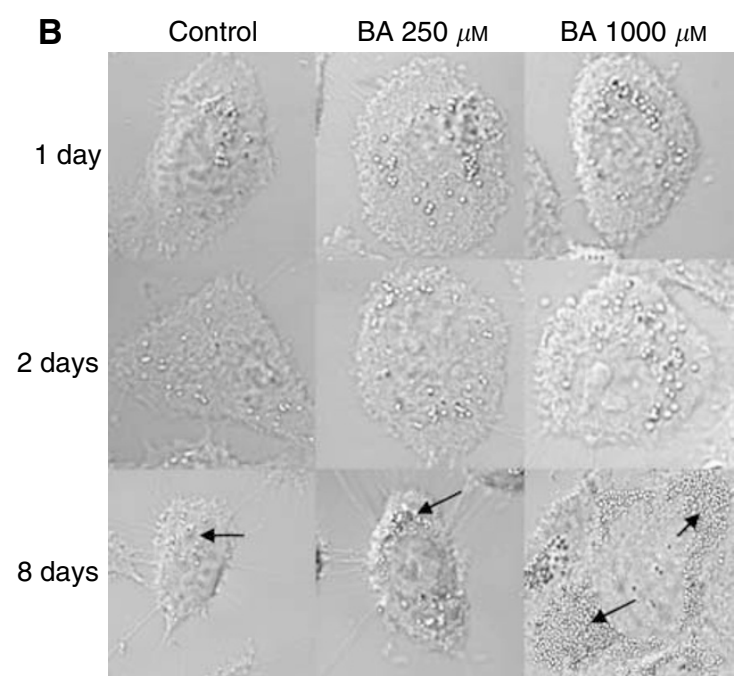

C

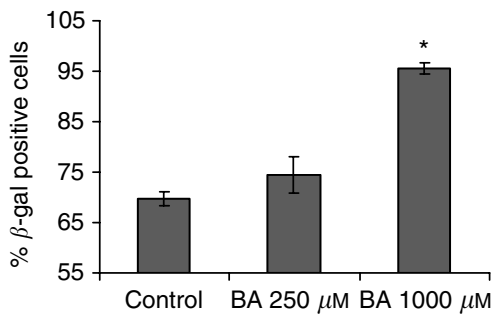

Figure I BA-induced morphological and senescent effects, following 8-day exposure, in DU-I45 cells. (A) Dose-dependent increase in granularity, by way of forward light scatter (FSC-H), and decrease in cell size, by way of side light scatter (SSC-H), from BA $(0-1000 \mu \mathrm{M})$ exposure, as presented on density plot; mean \pm s.e.m., $n=3$. (B) Confocal images $(63 \times)$ showing dose-dependent intracellular vesicle accumulation, as indicated by arrows, and flattened appearance at 8 days of exposure; whereas at I and 2 days cells remain unaltered. (C) Dose-dependent $\beta$-galactosidase activity (pH 4.0$)$ increase in DU-I 45 cells; mean \pm s.e.m., $n=4$. * Statistically significant from control exposures $(P$-value $<0.00$ I). 
A

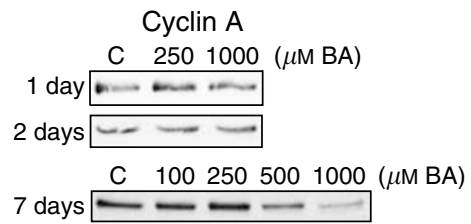

C

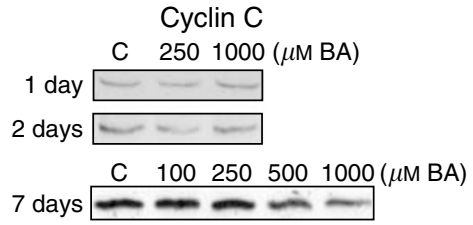

$E$

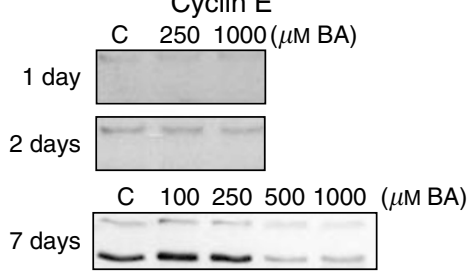

G

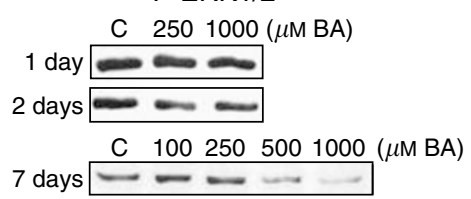

B Cyclin B1 C $2501000(\mu \mathrm{M} \mathrm{BA})$

1 day

2 days

7 days $-\quad 1002505001000(\mu \mathrm{M} \mathrm{BA})$

D

Cyclin D1

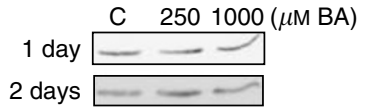

C $1002505001000(\mu \mathrm{M} \mathrm{BA})$

$\mathbf{F}$

P-MEK $1 / 2$

1 day $2 \quad 2501000(\mu \mathrm{M} \mathrm{BA})$

2 days $-\ldots$

C $1002505001000(\mu \mathrm{M} \mathrm{BA})$

7 days $\square-\cdots$

H

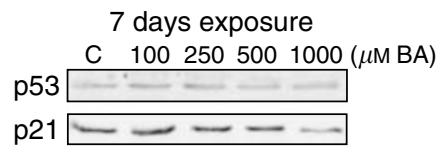

Figure 2 BA-induced alterations in proliferation-relevant protein expression, following I, 2, and 7-day exposure, in DU-I45 cells. (A-E) Western blots show dose-dependent BA-induced $(0-1000 \mu \mathrm{M})$ expression changes of cyclin proteins, $(\mathbf{F}, \mathbf{G})$ P-MEKI/2 and P-ERKI/2, and $(\mathbf{H})$ p53 and p2I.

\section{BA induces media acidosis and accumulation of acidic vesicles}

Acidic yellowing of phenol red in culture media was more pronounced in $\mathrm{BA}$ treated cells. The $\mathrm{pH}$ of media was measured prior to ( $\mathrm{pH} 7.4$ ) and following exposure to DU-145 cells for $24 \mathrm{~h}$, between the 7th and 8th days of culture. The $\mathrm{pH}$ for each concentration of BA $(0,250$, and $1000 \mu \mathrm{M})$ was then converted into an acidic shift from pH 7.4 per cell value. Chronically BA-exposed DU-145 cells acidified the surrounding culture media in a dosedependent manner (Figure 4A). The number of acidic vesicles (measured using Lysotracker fluorescent probe) also increased in a dose-dependent manner, but both the lysosome-specific LAMP-2 protein and early endosome marker EEA1 decreased (Figure 4B and C). The concentrations of BA used in culture media displays no significant effect on media $\mathrm{pH}$ (data not shown). To exclude the possibility that BA might alter the buffering capacity of densely populated culture plates, cells were cultured to near-confluence in control media before exposure to BA-supplemented media (250 and $1000 \mu \mathrm{M})$ for $24 \mathrm{~h}$. The $\mathrm{pH}$ remained unchanged at all BA concentrations, showing acidity was not associated with the media, but instead with cell changes that occurred during the 7 day exposure (data not shown).

\section{DISCUSSION}

Boron has a high affinity for oxygen and is present in aqueous solution, depending on $\mathrm{pH}$, as either $\mathrm{BA}\left(\mathrm{B}(\mathrm{OH})_{3}\right)$ or borate $\left(\mathrm{B}(\mathrm{OH})_{4}\right)^{-}$. Since the $\mathrm{pK}_{\mathrm{a}}$ of the equilibrium between $\mathrm{B}(\mathrm{OH})_{3}$ and borate $\left(\mathrm{B}(\mathrm{OH})_{4}\right)^{-}$is 9.2 , at intracellular $\mathrm{pH}(7.4)$ free boron exists as the weak Lewis acid, BA. BA, a small molecule with a mass of
61.83 , is rapidly absorbed from the human intestine and excreted via urine with a half-life of $21 \mathrm{~h}$ (Jansen et al, 1984, Schou et al, 1984). There is no evidence supporting metabolism of BA in any animal species (EPA, 1991). BA does bind to molecules with cishydroxyl groups, as established through mass spectrometry and NMR analysis identifying a high affinity for the ribose moieties of $\mathrm{NAD}^{+}$, and a somewhat lower affinity for mononucleotides (Kim et al, 2003). Nucleotide phosphorylation and loss of charge greatly reduces substrate affinity for BA (Kim et al, 2004).

\section{Morphology}

Flow cytometry analysis showed that BA caused a reduction in cell volume, yet under light microcopic investigation cells appeared to have a larger diameter. We believe the DU-145 cell line is responding to higher concentrations of $\mathrm{BA}$ by rearranging its cell shape into a flattened, low-volume state (Figure 3A). These structural alterations in shape and size are likely contributing to the inability of the cells to proliferate, since increased cell volume and a rounding up from the attached substrate are both critical events during mitotic division (Lang et al, 2000; Fujibuchi et al, 2005). The observation that morphological alterations did not appear following 1 and 2 day BA exposures, but did at 8 days, argues the changes reflect secondary response of long-term treatment with BA.

The relative intensity of fluorescent staining for G- and F-actin was found to be unchanged, regardless of BA concentration, indicating a steady-state actin pool ratio. Although actin concentrations in general appear unaltered, F-actin-stained filopodia extending about the periphery of the cells was reduced by $1000 \mu \mathrm{M}$ BA. With actin serving an important cytoskeletal factor 

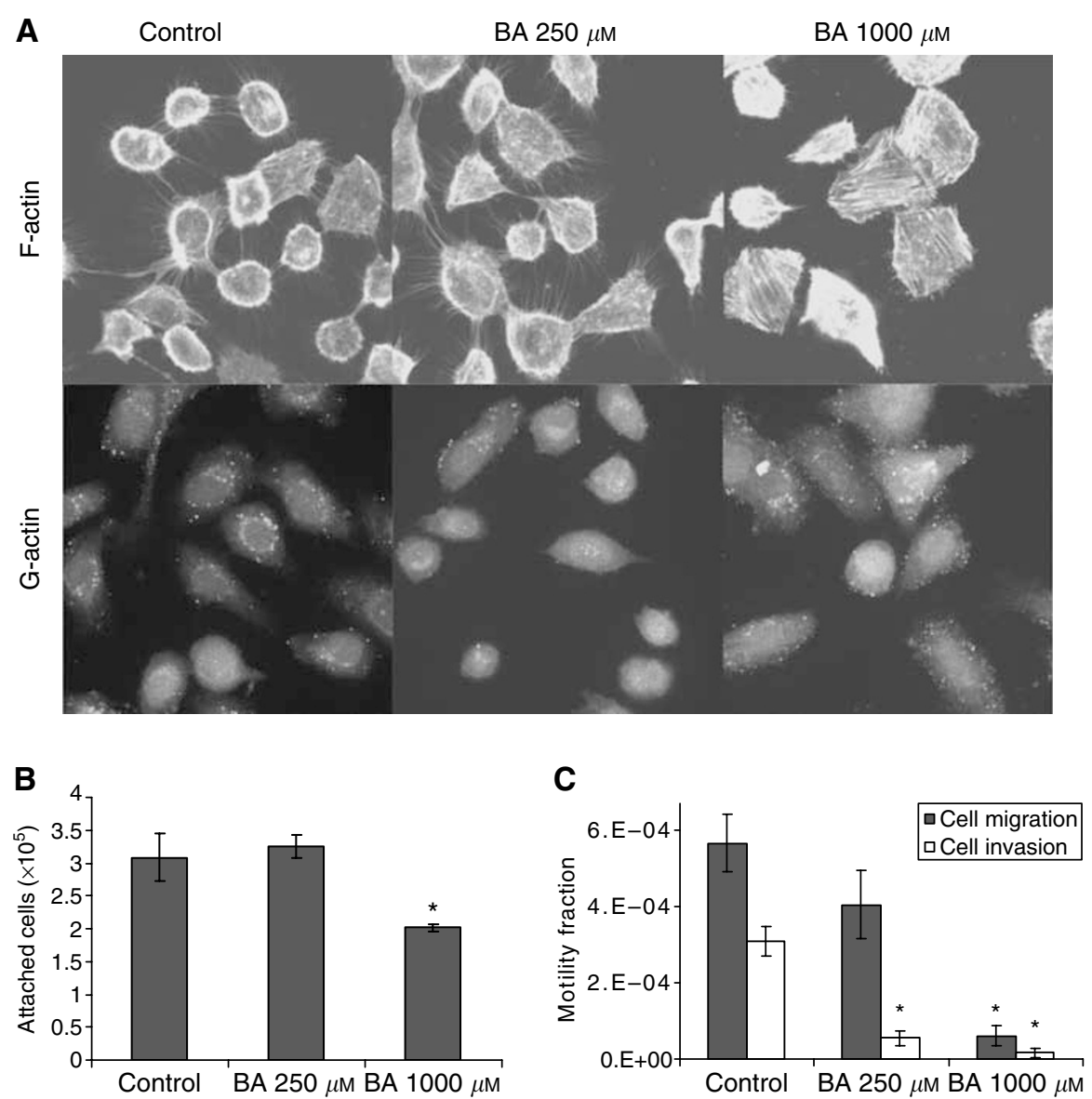

Figure 3 BA-induced changes in cell attachment, migration and invasion capacity, following 8-day exposure, in DU- 145 cells. $(\mathbf{A})$ Confocal images $(63 \times)$ of BA-treated $(0-1000 \mu \mathrm{M})$ cells showing F-actin filopodia retraction, yet no effect on G- or F-actin relative expression. (B) Reductions occurred in attachment efficiency. * Statistically significant from control exposures $(P$-value $<0.04)$. (C) Migratory and invasive capacity was reduced in treated cells; mean \pm s.e.m., $n=3$. * Statistically significant from control exposures $(P$-value $<0.02)$.

in cell migration and invasion (Lambrechts et al, 2004), the observed F-actin retraction in BA-treated cells suggests a reduced capacity to perform either. This interpretation was reinforced by the analysis showing a dose-dependent inhibitory effect on motility and invasion capacity, along with incompetence for reattachment (Figure 3B and $\mathrm{C}$ ). Together, these results suggest that $\mathrm{BA}$ reduces the metastatic potential of the DU-145 cell.

In BA-treated cells, granularity increased in proportion to exposure concentration, possibly due to the formation of intracellular vesicles (Figure $1 \mathrm{~A}$ and $\mathrm{B}$ ). The origin and content of these vesicles is unknown, since fluorescent probes for acidic compartments, tubulin, and intracellular calcium all failed to colocalise (data not shown).

\section{Proliferation}

The mechanism underlying the antiproliferative activity of BA has not been elucidated. One of the intriguing properties of BA is its ability to inhibit proliferation without causing a shift in cell cycle stage distribution or cell death (Barranco and Eckhert, 2004). In the current study, BA decreased the expression of five major cyclin proteins, all presumably playing significant roles in cell cycle progression (Figure 2A). Furthermore, the ability of antiproliferative agents to inhibit the expression of these proteins is important, since cyclins A, B1, E, and D1 have been correlated with prostate cancer aggressiveness (Mukhopadhyay et al, 2002; Maddison et al, 2004; Tsao et al, 2004).
The DU-145 cell line has a mutant p53 protein incapable of signalling through $\mathrm{p} 21$, so it was nonetheless surprising to see $\mathrm{p} 21$ expression reduced by BA exposure (Figure 2B) (Lecane et al, 2003). The downregulation of p21 helps to explain why BA does not shift DU-145 cell populations into a G1 arrest (Barranco and Eckhert, 2004, Shukla and Gupta, 2004).

BA's effects on growth has been shown to be parabolic in embryonic trout and zebrafish with poor embryonic growth occurring at very low and high concentrations (U-shaped curve) (Rowe et al, 1998). BA's growth effects are cell-type dependent with maximum growth occurring in Saccharomyces cerevisiae cells at $<0.8 \mu \mathrm{M} \mathrm{BA}$, whereas $500 \mu \mathrm{m}$ of BA maximised proliferation in HeLa cervical cancer cells (Bennett et al, 1999; Park et al, 2004). Furthermore, in HeLa cells BA $(300 \mu \mathrm{M})$ was shown to stimulate the MAPK pathway in a bell-shaped fashion, with an initial induction of P-MEK1/2 and P-ERK1/2, followed by a decline in expression of $\mathrm{P}-\mathrm{MEK} 1 / 2$ over time. In the present study, BA reduced P-MEK1/2 expression in a dose-dependent manner, yet increased P-ERK1/2 moderately at $250 \mu \mathrm{M}$ (Figure $2 \mathrm{~F}$ and $\mathrm{G}$ ). By way of Ras/Raf signalling, the phosphorylated form of MEK phosphoylates ERK, which then translocates to the nucleus and activates transcription factors relevant in proliferative induction. Thus, by upregulation of this pathway's activity, it appears that DU-145 cells are attempting to counter the BA-induced growth inhibition (Giehl, 2005). Expression of MEK, ERK, and all cyclins were not altered following 1 and 2 day treatments suggesting, as observed with cell morphological changes, these were not the primary effect of BA. 
A
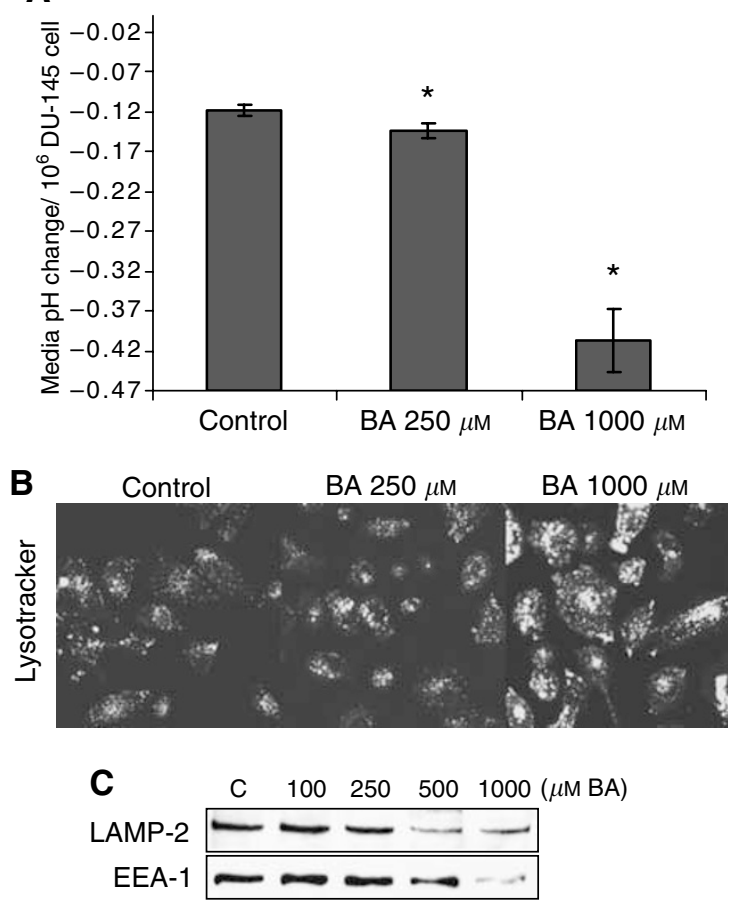

Figure 4 BA-induced media $\mathrm{pH}$ shifts and acidic vesicle accumulation, following 8-day exposure, in DU-I 45 cells. (A) pH shifts from 7.4 (per 106 cells) recorded in BA-supplemented $(0-1000 \mu \mathrm{M})$ culture media, following overnight exposure, subsequent to 8-day treatment; mean \pm s.e.m., $n=3$. * Statistically significant from control exposures ( $P$-value $<0.009)$. (B) Confocal microscopic images of BA-treated cells with Lysotracker (fluorescent marker of intracellular acidic compartments). (C) 7-day BA treatments $(0-1000 \mu \mathrm{M})$ led to downregulation of lysosome (LAMP-2) and the early endosome (EEAI) markers, as shown in Western blots.

\section{Senescence}

DU-145 cells were evaluated for $\beta$-galactosidase activity, a marker of senescence or reversible cellular quiescence (Coates, 2002). When enzymatic activity is measured at $\mathrm{pH} 4.0$, it is thought to indicate an increase in lysosomal enzyme concentration, whereas enhanced activity at $\mathrm{pH} 6.0$ reflects an increased lysosomal mass (Kurz et al, 2000). In our study, BA treatment increased the activity of $\beta$-galactosidase in a dose-dependent manner at $\mathrm{pH} 4.0$, yet no activity was apparent at $\mathrm{pH}$ 6.0. However, the dose-dependent increase recorded at $\mathrm{pH} 4.0$ suggests the BA induces some 'senescent-like' characteristics.

\section{REFERENCES}

Barranco WT, Eckhert CD (2004) Boric acid inhibits human prostate cancer cell proliferation. Cancer Lett 216: $21-29$

Bennett A, Rowe RI, Soch N, Eckhert CD (1999) Boron stimulates yeast (Saccharomyces cerevisiae) growth. J Nutr 129: 2236-2238

Bone R, Shenvi AB, Kettner CA, Agard DA (1987) Serine protease mechanism: structure of an inhibitory complex of alpha-lytic protease and a tightly bound peptide boronic acid. Biochemistry 26: 7609-7614

Chen X, Schauder S, Potier N, Van Dorsselaer A, Pelczer I, Bassler BL, Hughson FM (2002) Structural identification of a bacterial quorumsensing signal containing boron. Nature 415: 545 - 549

Coates PJ (2002) Markers of senescence? J Pathol 196: 371-373

Cui Y, Winton MI, Zhang ZF, Rainey C, Marshall J, De Kernion JB, Eckhert CD (2004) Dietary boron intake and prostate cancer risk. Oncol Rep 11: $887-892$

\section{Accumulation of acidic intracellular vesicles}

A peculiar manifestation of BA treatment was discovered when the media of chronically exposed DU-145 cells became increasingly acidic (Figure 4A). This effect was dose-dependent and not due to changes in the buffering capacity of the media or BA itself. The documented accumulation of acidic intracellular compartments is supportive of an affiliation with the media $\mathrm{pH}$ shift, by either contributing directly to the environmental acidification, or rather resulting from it, as seen in breast cancer cells (Glunde et al, 2003). Initially, we believed the upregulation of acidic vesicles reflected an increase in lysosome organelles, yet the LAMP-2 protein, expressed on lysosomal membranes in prostate tissue, decreased in expression (Figure 4C) (Furuta et al, 1999). It was also possible that the acidic vesicles were early endosomes, yet the protein expression of early endosome marker EEA-1 was likewise reduced (Eskelinen et al, 2003). Further studies are needed to determine if this response is unique to cancer cells or a universal response to BA (Gatenby and Gillies, 2004). Interestingly, metabolic acidosis has been reported in a case of fatal BA poisoning (Restuccio et al, 1992).

\section{Conclusion}

The rationale for this study was based on the fact that BA is (i) a natural constitute of human blood, (ii) readily absorbed with plasma levels determined by dietary intake, and (iii) there is epidemiological, animal, and cell culture evidence supporting its antiproliferative capacity in prostate cancer. In this report, we show that pharmacologically-relevant BA treatment causes DU-145 prostate cancer cells to convert to highly granular, low-volume, flattened cells that have a marked reduction in their capacity to migrate, invade matrigel, and attach to synthetic substrates. Reduction in the expression of proliferation-relevant proteins, along with the upregulation of $\beta$-galactosidase activity, ultimately leads to a nonproliferating entity reminiscent of a senescent-like cell. Finally, the resulting cell accumulates intracellular acidic vesicles, while acidifying its extracellular environment.

\section{ACKNOWLEDGEMENTS}

We thank Dr Allan Pantuck and Randy Kallilew for their expertise concerning cell culture. With the help of Michael Gulrajani, flow cytometry was performed in the UCLA Jonsson Comprehensive Cancer Center (JCCC) and Center for AIDS Research Flow Cytometry Core Facility that is supported by National Institutes of Health awards CA-16042 and AI-28697, and by the JCCC, the UCLA AIDS Institute, and the David Geffen School of Medicine at UCLA. Grant support: DOD prostate idea Grant DAMD17-03-10067 (CD Eckhert) and UC TRS\&TP (WT Barranco).
Dimri GP, Lee X, Basile G, Acosta M, Scott G, Roskelley C, Medrano EE, Linskens M, Rubelj I, Pereira-Smith O, Peacocke M, Campisi J (1995) A biomarker that identifies senescent human cells in culture and in aging skin in vivo. Proc Natl Acad Sci USA 92: 9363 -9367

Environmental Protection Agency (1991) Health and environmental effects document for boron and boron compounds. Report EPA6008-91015; Order No. PB91-233635: 1-269

Eskelinen EL, Tanaka Y, Saftig P (2003) At the acidic edge: emerging functions for lysosomal membrane proteins. Trends Cell Biol 13: $137-145$

Fujibuchi T, Abe Y, Takeuchi T, Imai Y, Kamei Y, Murase R, Ueda N, Shigemoto K, Yamamoto H, Kito K (2005) AIP1/WDR1 supports mitotic cell rounding. Biochem Biophys Res Commun 327: $268-275$ 
Furuta K, Yang XL, Chen JS, Hamilton SR, August JT (1999) Differential expression of the lysosome-associated membrane proteins in normal human tissues. Arch Biochem Biophys 365: 75-82

Gallardo-Williams MT, Chapin RE, King PE, Moser GJ, Goldsworthy TL, Morrison JP, Maronpot RR (2004) Boron supplementation inhibits the growth and local expression of IGF-1 in human prostate adenocarcinoma (LNCaP) tumors in nude mice. Toxicol Pathol 32: 73-78

Gallardo-Williams MT, Maronpot RR, Wine RN, Brunssen SH, Chapin RE (2003) Inhibition of the enzymatic activity of prostate-specific antigen by boric acid and 3-nitrophenyl boronic acid. Prostate 54: 44-49

Gatenby RA, Gillies RJ (2004) Why do cancers have high aerobic glycolysis? Nat Rev Cancer 4: $891-899$

Giehl K (2005) Oncogenic Ras in tumour progression and metastasis. Biol Chem 386: $193-205$

Glunde K, Guggino SE, Solaiyappan M, Pathak AP, Ichikawa Y, Bhujwalla ZM (2003) Extracellular acidification alters lysosomal trafficking in human breast cancer cells. Neoplasia 5: $533-545$

Jansen JA, Andersen J, Schou JS (1984) Boric acid single dose pharmacokinetics after intravenous administration to man. Arch Toxicol 55: $64-67$

Kim DH, Faull KF, Norris AJ, Eckhert CD (2004) Borate-nucleotide complex formation depends on charge and phosphorylation state. J Mass Spectrom 39: $743-751$

Kim DH, Marbois BN, Faull KF, Eckhert CD (2003) Esterification of borate with NAD+ and NADH as studied by electrospray ionization mass spectrometry and 11B NMR spectroscopy. J Mass Spectrom 38: $632-640$

Kurz DJ, Decary S, Hong Y, Erusalimsky JD (2000) Senescence-associated (beta)-galactosidase reflects an increase in lysosomal mass during replicative ageing of human endothelial cells. I Cell Sci 113: 3613-3622

Lambrechts A, Van Troys M, Ampe C (2004) The actin cytoskeleton in normal and pathological cell motility. Int J Biochem Cell Biol 36: $1890-1909$

Lang F, Ritter M, Gamper N, Huber S, Fillon S, Tanneur V, LeppleWienhues A, Szabo I, Gulbins E (2000) Cell volume in the regulation of cell proliferation and apoptotic cell death. Cell Physiol Biochem 10: $417-428$
Lecane PS, Kiviharju TM, Sellers RG, Peehl DM (2003) Leptomycin B stabilizes and activates p53 in primary prostatic epithelial cells and induces apoptosis in the LNCaP cell line. Prostate 54: 258-267

Maddison LA, Huss WJ, Barrios RM, Greenberg NM (2004) Differential expression of cell cycle regulatory molecules and evidence for a 'cyclin switch' during progression of prostate cancer. Prostate 58: 335 - 344

Mukhopadhyay A, Banerjee S, Stafford LJ, Xia C, Liu M, Aggarwal BB (2002) Curcumin-induced suppression of cell proliferation correlates with down-regulation of cyclin D1 expression and CDK4-mediated retinoblastoma protein phosphorylation. Oncogene 21: 8852-8861

Park M, Li Q, Shcheynikov N, Zeng W, Muallem S (2004) NaBC1 is a ubiquitous electrogenic $\mathrm{Na}+$-coupled borate transporter essential for cellular boron homeostasis and cell growth and proliferation. Mol Cell 16: $331-341$

Price CJ, Strong PL, Murray FJ, Goldberg MM (1997) Blood boron concentrations in pregnant rats fed boric acid throughout gestation. Reprod Toxicol 11: $833-842$

Restuccio A, Mortensen ME, Kelley MT (1992) Fatal ingestion of boric acid in an adult. Am J Emerg Med 10: $545-547$

Rowe RI, Bouzan C, Nabili S, Eckhert CD (1998) The response of trout and zebrafish embryos to low and high boron concentrations is U-shaped. Biol Trace Elem Res 66: $261-270$

Schou JS, Jansen JA, Aggerbeck B (1984) Human pharmacokinetics and safety of boric acid. Arch Toxicol Suppl 7: 232-235

Semmelhack MF, Campagna SR, Hwa C, Federle MJ, Bassler BL (2004) Boron binding with the quorum sensing signal AI-2 and analogues. Org Lett 6: $2635-2637$

Shukla S, Gupta S (2004) Molecular mechanisms for apigenin-induced cell-cycle arrest and apoptosis of hormone refractory human prostate carcinoma DU145 cells. Mol Carcinog 39: 114-126

Sobel RE, Sadar MD (2005) Cell lines used in prostate cancer research: a compendium of old and new lines - part 1. J Urol 173: 342-359

Takano J, Noguchi K, Yasumori M, Kobayashi M, Gajdos Z, Miwa K, Hayashi H, Yoneyama T, Fujiwara T (2002) Arabidopsis boron transporter for xylem loading. Nature 420: $337-340$

Tsao AS, Kim ES, Hong WK (2004) Chemoprevention of cancer. CA Cancer J Clin 54: $150-180$ 